\title{
THE PRINCIPLE OF THE FRAGILITY OF GOOD THINGS
}

At the top of any trajectory lies a point of singularity. Within that singularity, a confluence of smooth alterations. An object's behavior changes. Rome falls. Balloons burst. Forces build until friction gives way. Life follows the same pattern. Time controls life. Air controls the balloon. Each is controlled by a single factor. At first, TwA Flight 800 seemed to follow this, the simplest model, of Catastrophe Theory. As it climbed through 13,800 feet, an explosion ripped through the airplane's belly. The nose broke off; the plane pitched up.

But Flight 800 had less in common with Rome or balloons than it had with the mood swings of a manic depressive or the hostility of warring nations. It belonged to the Cusp Catastrophe, the most common occurring for two control factors. Latent Conditions lie dormant. They are the high and low voltage wires held together in thick bundles that have gone unchecked since their installation. Active Errors are those committed by people in immediate contact with the system. They are the 13 gallons of fuel left in the 50,000-gallon center fuel tank above the air conditioners, which ran for two hours on a hot tarmac. Latent Conditions do no harm until they interact with Active Errors. Catastrophe Theory describes this as The Principle of the Fragility of Good Things: all good things are more fragile than bad things. Stability is more fragile than instability. All happy families are alike. Every unhappy family is unhappy in its own way.

Elaine Scarry writes that when we see something beautiful, it is lifesaving. It acts like a small tear in the surface of the world that pulls us through some vaster space. If the object of beauty ceases to be beautiful, she asks, has it defaulted on its promise? In an abstract way, this question appeared as early as 1982 when an Air Florida 737 crashed into the Potomac River during a January snowstorm. Flight 90 was headed back to Tampa. If it had cleared the 14th St. Bridge, and if the breeze off the Gulf had been right, we might have watched its final descent from our balcony. Instead, we watched the cheerful swirling design on the tail of Air Florida cut like the fin of a shark through the icy Potomac. We're going down, said the second officer to the captain. We're not gonna make it, said one seatmate to another. For two years, the 
awe of the $727 \mathrm{~s}$ and $737 \mathrm{~s}$ had slowly dissolved with the whir of the motors, the throttle of the engines, the thump of the landing gear. While my mom picked the lice we contracted in The Spring from our vinegar-soaked hair, we watched on the news images of passengers clinging to chunks of ice. A man jumped into the river to save a woman. A woman shouted for her baby. The comb pulled the long, tangled strands. Outside, the ground rumbled. Inside, the windows rattled. When the 747 arrived like a small tear in the surface of the world, the air above and below it quivered as though the responsibility for keeping it aloft had become too great. It hurts to be beautiful, she said.

In a less abstract way, the object of beauty had defaulted on its promise when TwA Flight 800 crashed. The 747 that was Flight 800 , it seemed, was no longer an airplane, but a bygone fantasy, the culmination of a mythology that began 990 years earlier when Eilmer of Malmesbury constructed wings like those of a glider and jumped from the tower of the Malmesbury Abbey. Scholars dismiss early accounts attributing Eilmer's flight to the Daedelus myth. The culture of Anglo-Saxon England in the late tenth and eleventh centuries was, after all, one of "progressive character" and "advanced conditions" and "daring originality." Examples were made of the manner in which depictions of the ascension of Christ were portrayed. Where earlier portrayals had Him passively ascending on a cloud or carried up by angels, now Christ appeared "jet-propelled" and "zooming heavenward." One thousand years later, as I stood in front of the reconstructed fuselage of TWA Flight 800 , as unprepared as anyone who first glimpses the disfigured features of an embalmed loved one, I could see that this 747-in less than two minuteshad done for crashing exactly what it had done for flying: gaps between pieces of fuselage skin allow a glimpse into the forward cabin, where 400 $\mathrm{MPH}$ winds blew during the initial break-up. Passengers seated here, found covered in purple, yellow, and green theater glitter that had blown through the cargo hold, bore the brunt of the explosion. They suffered a whiplash so violent it separated their skulls from their spinal cords. Heads were left brainless, faces disfigured, limbs torn off. Thousands of pieces of metal and debris riddled their bodies. Compression fractures shortened them by several inches. Fingerprints were required to match hands.

These are not findings turned out by the survival factors group or the recollections of the pathologist, who reportedly described performing the autopsies as akin to "doing brain surgery on a roller coaster." They are not written on placards mounted in front of the reconstructed fuselage or on those 
reverently placed and maintained at the Flight 800 memorial in Shirley, New York. These are the grim particulars tucked far into New York Times articles following the crash of TWA Flight 800. Among them were those reassuring the reading public that although sharks and crabs nibbled away at their loved ones on the ocean floor, and although water and blood in the lungs indicated that some passengers were still breathing and although skull fractures and bleeding in the brain suggested that some were still alive when they hit the water, these passengers were not necessarily conscious.

When I was young, the Stations of the Cross told us The Story: given a heavy cross to carry a long way, Jesus silently shouldered his burden. When, at Station 6 , a nice woman offered her veil to clean the blood and sweat from his face, Jesus left the image of his suffering on the veil. At Station 14, we imagined a time we were very sad to say good-bye. Could we imagine such suffering in our own lives? The only examples I brought to mind were the bedposts my sister repeatedly flogged with beloved stuffed animals and the Adam Walsh kidnapping in Hollywood, Florida. Adam and I were the same age when he wandered off in a department store. Following the disappearance, his face, flushed and freckled and missing front teeth, appeared in newspapers and on television. Beneath the bill of a baseball cap, his sweatdampened hair stuck to his forehead. A bat perched, ready to swing. There was something wrong with a society that had procedures for tracking stolen vehicles but none for stolen children. When his head was discovered floating in a canal, I easily brought to mind the red baseball cap, the missing teeth, but I fixated on the part of the story I couldn't envision. "What's a canal?" I asked.

Recently, I called my sister, who was just four and a half when Adam disappeared. Expecting her to corroborate only vague details, I was surprised when she told me his mother had been shopping for lamps at Sears and had ALLOWED him to walk four aisles over to watch some older boys play video games. My sister has two young boys of her own. The subject of Adam Walsh had actually just come up, she told me, because her older son, along with another neighborhood boy, had snuck off to a gas station a few hundred yards from where they lived.

"How do you think it feels to have someone cut your head off?" she asked him when he returned. "You said that?" I asked. 
"I said people do horrible, unimaginable things to children. If someone takes you, they're going to cut off your feet and put them in a freezer."

That my head could have been floating in a canal instead of Adam Walsh's was a possibility not entirely lost on me when, six months after his discovery, we arrived at The Spring. The women and children living at The Spring were all sufferers in a place that for me became, rather than the new beginning the name was meant to imply, the apotheosis of all suffering. We lived in the basement with another mother and her three young children, including a newborn Mom cared for when the woman went to work. At The Spring, the water ran sulfurous and cold. Fevers ran high. Worse still was the school my sister and I temporarily attended and would later refer to as The Shelter School. It made the biweekly masses in pressed uniforms and knee-socks, the orderly lines we formed, and the obedience with which we practiced penmanship at our Catholic school look like a Montessori. Frequent disruptions came less from the students than from the teacher's preemptive attempts to thwart them. Yardsticks, rulers, old wooden pointers smacked and rapped and taunted. Students spent more time standing in corners awaiting a paddling than they did reading or subtracting. The message at Station 15, that Jesus was alive in a whole new way, suggested that the suffering had paid off: the captain has turned off the "fasten seat belt" sign; you are now free to move about the cabin. As I was accustomed to kneeling before a man wearing a crown of thorns and nailed to a cross, it was all very comforting. I looked up at him, not with the horror and fascination with which I'd watched David Naughton turn into a werewolf in a London flat, but with the reverence of a child raised to revere martyrdom. Had I been looking up, instead, at Hypatia after she had been flayed alive with oyster shells, I might have prayed for something other than leaving The Spring. But I prayed to leave. One weekend when Dad failed to return us to the designated meeting post between Town and Country and downtown Tampa, my prayers were answered.

I sent away to the National Transportation Safety Board training center for a course catalog and received along with it a glossy brochure brimming with photographs of the reconstructed fuselage of TWA Flight 800. The brochure explained that the reconstructed fuselage of TWA Flight 800 was exclusively for teaching investigators how to use reconstruction techniques to solve and prevent future accidents. Out of respect for the friends and family of victims, it was not open for public viewing. I was put in touch with the head of the 
survival factors group, who told me over the phone that one reason why survivability is studied is to help dispel the public perception that most aircraft accidents are not survivable. Ninety percent are, and of the fifteen hundred passengers who die annually, six hundred should survive. To increase survivability, it is necessary to provide a factual account of what happens during these accidents. When she asks why I want to take the forty-hour course culminating in my certification as a representative member of the survival factors group, I tell her that a fear of flying occupies a larger space among non-experts and that I am interested in the technical, institutional, and regulatory side of flying, the side that tells us how and why we survive.

"You're interested in outreach, then?"

Yes. Exactly. Outreach. And reading what I had composed off the sheet of paper in front of me: "My goal is to provide a basis for understanding a fear of flying, its cultural significance, its place in our psychology as a society."

When she doesn't respond, I tell her I've interviewed some commercial air disaster survivors. And when she asks which crash, I tell her United Flight 232.

"I worked that crash," she says. "Who have you interviewed?"

Though I intended to, I hadn't actually interviewed anyone.

A long pause on the other end of the phone has me considering whether I should fill it with the recent discovery that my uncle flew Charlton Heston to Sioux City for the making of the movie on Flight 232, A Thousand Heroes.

"So you want to work with people who have a fear of flying?" she asks.

I look down at my sheet. "I want to help people understand a subject that is badly understood and to create an opening in which a new discourse can occur."

"It's gruesome work," she says, "that's complicated by the fragmentary nature of the evidence. We make you do exactly what we do. You'll be in a hazmat suit picking through real wreckage and debris."

What I don't tell her is that I am dying to see the 60,000 pounds of the 1,600 dredged-up, reconstructed pieces of TwA Flight 800 after 4,344 total dives and 1,773 total diving hours by more than 225 divers who likened the dredging to "walking barefoot on razor wire" and "being lowered into hell," divers who were not prepared to tag oil-slicked limbs detached from torsos or to disentangle bodies whose faces were locked in a final expression of horror from miles of cable and wire buried beneath chunks of the airplane; men who thought it was grisly, but not as grisly as the ValuJet crash in the 
Everglades a few months earlier, where no piece of the airplane was bigger than a dinner plate.

I don't tell her that I need to see Flight 800 in person, that I want to get as close to it as possible, possibly even touch it. I want to run my hand over its dredged-up, jagged edges in the same way I like to run my hand over the smoothness of the airplane I am about to board and silently tell it to please be okay.

The day before I arrive at the NTSB training center, I receive a call from my uncle the airline pilot, whose regular route takes him through Reagan International. We'll miss each other the week of survival factors, but his girlfriend, Mollie, will happily keep me company. No need to trouble Mollie, I explain. Days of mock-disaster investigations and survival lectures-not to mention the reconstructed fuselage of Flight 8oo-will leave me little time and energy for social engagements. Besides, I've never met Mollie. What little I know of her I learned from my dad, who described her as "clad in a midriff" with "a pierced navel," wearing "butt-shorts" that read "Trouble." Literal truths do not agree with my father, and while I am suspect of the details, I know that together they mean to convey a larger emotional truth, a how-it-felt-to-me truth I recognize in my own disquisitions. This larger emotional truth is less a statement about Mollie than it is about my uncle, whose habits range from the eccentric to the reckless. Eccentric is his habit of breeding rabbits and rats and building them flying devices: miniature hot air balloons, remote-control model airplanes, and tiny parachutes. Reckless is his flying into illegal airspace or running out of gas, landing his plane on a beach or on a frontage road during rush hour and fleeing the scene. Mollie fit into the latter.

Several short conversations ensue. All prematurely cut off by either Mollie's incoming phone calls or my uncle's need with each fresh clarification to call Mollie. Over the course of these conversations, I walk from the Extended Stay to the mall for an iced coffee. Outside temperatures are already hovering in the mid-nineties with humidity pressing into triple digits. By the time I enter the mall, my face is red and my shirt is soaked. "Since I'm here at the mall," I say to my uncle, "might it make more sense for Mollie and me to just work out the details between us?" This opens up a new line of inquiry. "What mall?" asks my uncle. "What would possess you to go to a 
mall? There are no malls near the NTSB training center. You're not at a mall. Where are you? Hold on. It's Mollie."

My uncle had done several tours in Iraq. His job was to refuel fighter jets-while they were in the air. Flying refueling jets, he said, was the least stressful activity for him in Iraq. Back at the Baghdad Airport, he wrote angry letters to congressmen about the egregious waste of natural resources: the personnel who spent their days sitting in air-conditioned suvs, the disposable place settings used for each meal, the detritus from Desert Storm still littering the landscape. This is where your tax dollars are going, he told me in the summer of 'O2. You need to hang up the phone and start writing letters. My uncle is an avid letter writer. The whole family writes letters. I understand the instinct as a kind of public prayer, a declaration of desire bound to the conditional. During their divorce, my dad had written my mom a letter whose contents merely stated that if she wanted the television set, she was to take the letter to my uncle, who upon receipt of it would return the television. I remember this because my mom's refusal to participate in the charade meant that we would not have a TV. Over the years, everyone in the family had drafted letters to a multitude of affiliations. Granny's favored upper management-usually service industries-for neglecting to provide proffered or satisfactory amenities. Full refunds or free vouchers usually resulted, beginning the cycle anew. My aunt's were directed at publishers and editors of the calculus and statistics books through which she taught. Word problems dragging dangling modifiers or begging proper punctuation were, as the semester progressed, tallied on inside covers and relayed in polite but firm dispatches. My uncle's letters differed only in advancing solutions. As much as he revered letter writing and flying airplanes he reviled waste and inefficiency. Short of a return to the horse-and-buggy days of yore, ways to a safer, greener, more cost- and fuel-efficient America began with the stoplight. If you are a suburban Chicago driver, you will have noticed subtle changes: the red light now blinks its warning. A sign reading "no turn on red" has been replaced with a flashing arrow. Thanks to my uncle, rather than waiting and idling at stoplights, cars move unencumbered through traffic-less intersections.

Mollie arrives in front of Macy's in a convertible. Her heavy maroon hair drapes down her bare shoulders. A Misty Light 120 dangles from her lips. "Berneeee!" she yells. The convertible idles. "Are you Bernie?" Far from the twenty-two-year-old I had envisioned, Mollie is middle-aged. She leaps 
from the car and clomps over in a pair of mules, one ankle festooned with gold bracelets. Her torso, covered only by a black bikini top and several gold charms suspended in the shadow of her cleavage, is cinched at the waist with a pair of white cut-offs. She embraces me with the enthusiasm of a long-lost cousin. "Where's your bathing suit?" she asks. "I told your uncle to tell you to bring a bathing suit. God damn him." As we pull out of the parking lot, her cell phone rings. "No, I'm not smoking!" she screams. "Yeah, I got her. She's right here. No. I took the convertible." I hear my uncle yelling about UV rays, lung cancer, and talking while driving. Mollie throws the phone and reaches for another cigarette. "I've got a restraining order against your uncle. For one, he shook my kid. For two, he tried to kill me."

We arrive first at an Irish pub, where I am dubiously received as my uncle's niece. After sharing a pitcher, we drive to Mollie's, ostensibly so I can borrow a bathing suit. Cherry trees line the neighborhood outside her suburban Alexandria home. Helmetless children ride bicycles and balding fathers mow lawns. Inside, fresh vacuum prints streak across heavy beige carpeting. Understated kitsch—polished and dusted — rests on doilies and glass tabletops. The walls similarly covered in bouquets of eucalyptus, gilt mirrors, and photographs, accent faux plants in wicker baskets. It feels like the homes of my childhood friends, the ones I envied growing up. There are probably graham crackers in the cupboard and sugary cereals lining the pantry. Photographs clutter the hallway wall and the top of a piano. Here she introduces me to her children, both of whom are with their respective fathers for the weekend. I don't ask which one had been shaken. Mollie babysits for a living. Photos of these children also fill the frames. One by one, she recounts personalities and ages and time spent with them at her house, until all of the narratives have been disclosed, and only one photo remains. Sepia-tinted with age, it depicts a young woman in her late teens or early twenties posing against the railing of a staircase. For a moment, I gauge Mollie against the photo. "I like this one," I say. "Who is it?" The trill in Mollie's voice fades. "That's my mom. And my sister."

It has been nearly a decade since Flight 800 exploded over Long Island Sound when I arrive at the NTSB training center. CNN is scheduled to air a two-part documentary interrogating the safety of combustible fuel/air vapor in large passenger jets: CNN Presents: No Survivors-Why TWA Flight 800 Could Happen 
Again. What is not insinuated in the title has already been seared into the mind of anyone remotely cognizant during the summer of 1996: the length and scope of the investigation, the recovery and the treatment of wreckage and victims as criminal evidence, the speculations into the cause, and the manner in which those speculations were dispensed to the media by law enforcement officials and disaster investigators and then to the lay public by the media: Investigators See "Eerie Similarities" with Other Airliners That Blew Up, Another Decapitated Jet, Another Pan Am 103 over Lockerbie, Prime Evidence Found That Device Exploded in Cabin, Components from Bombs and Missiles Came From Wreckage, Jet's Landing Gear Is Said to Provide Evidence of a Bomb, and Explosion Aboard TWA Flight 8oo: Terrorism.

Speculations were corroborated by a confluence of disparate events occurring in and around the crash. A truck bomb two weeks earlier in Saudi Arabia had killed nineteen Americans at Khobar Towers. Ramzi Yousef was on trial in New York City for his plot to blow up twelve airliners over the Pacific Ocean. And, less than two weeks later, a suspicious package would explode in Centennial Olympic Park in Atlanta. Some officials had cautioned against speculation, but "personal opinions" by those in positions of power centered around Algerian fundamentalists, anti-American groups in the Middle East, and Middle Eastern terrorist groups with links to Libya or Iraq, who, according to some, "could have found easier targets closer to home." As the culminating event of the century and, ultimately, the millennium, the crash rendered TwA Flight 800 less an emblem of prospect than one of conjecture.

"There is something unique about TWA; it doesn't quite fit the mold," industry historian Robert Sterling declared in 1983. TWA had already enjoyed sixty years as a forerunner in flight. Shortly after beginning as an airmail delivery company in the '2os, it entered the commercial market. By the ' 30 , it was flying coast-to-coast; during the '4OS, it offered regular service from New York to Paris; in the '5os, it began nonstop service between L.A. and New York; and in the late '6os, it was the first to offer 747 service in the U.S. Earlier in the decade, talk among airlines hinted at the growing number of travelers. The steady increase would require a much larger jet. According to airplane lore, Pan Am wrote Boeing a letter:

Dear Mr. Boeing,

Please build us a very big airplane. 
If it is pretty, all the better.

We will buy lots of them.

Yours Sincerely,

Pan Am

Building a very big airplane would be risky. Development and construction alone required 50,000 people; 1,500 subcontractors; 4.5 million parts; 75,000 engineering drawings; a facility large enough to hold 43 football fields; and engines more powerful and more reliable than those of any other airplane. Almost three times the size of the largest existing passenger jet, the 747's tail would rise six stories high, the wingspan would stretch longer than the Wright brothers' first recorded flight, and the fuel tanks would hold up to 380,000 pounds of fuel. And if this very big, very pretty airplane were to crash, it would leave more dead than any single previous year's combined total.

New airplanes are required to undergo a quantitative evaluation to assess potential system failures. Probability parameters for these failures are set based on the consequences of the failure. In the building of the 747 , engineers were using a new "top-down" deductive method for spotting potential failures called Fault Tree Analysis. The fault tree resembles a complicated version of the family tree. Based on Reliability Theory and Boolean logic, it requires the user to first identify the "fault," then trace a backwards map of possible contributing elements.

At the time of certification for the 747, there were probability parameters for possible minor and major failures, but none for catastrophic failures. Terms stated that "Airplane systems must be designed so that the occurrence of any catastrophic failure (a condition that would compromise the continued safe flight and landing of the airplane) is extremely improbable." Extremely Improbable meant that the occurrence was "so unlikely that it was not anticipated to occur during the entire operational life of all airplanes of one type." As such, the 747 that became TwA Flight 800 was not required to undergo a Fault Tree Analysis for its certification. Thirty years later, when Flight 800 suffered a catastrophic failure thirteen minutes after takeoff, a fault tree was constructed. The ignition of the Center Wing Tank was identified as the "fault." But some of the contributing elements in the fault tree were, according to the NTSB, "not reflecting the results of the on-going investigation." And some of the numbers, according to NASA Space Flight Center 
personnel, "appeared overly optimistic." When the Board asked Boeing to revise the fault tree, Boeing responded:

We do not believe that revising the fault tree analysis by incorporating new data or changing the probability numbers will help identify new areas to inspect or help identify the cause of the accident. We believe it would be more productive to continue the various inspection and modification programs that are presently underway.

The Fault Tree Analysis, according to Boeing, supported only the investigation. Because it had not gone through an iterative review process in its certification, valuable data that might have offered clues into catastrophic failure modes were not available. The Safety Board dismissed this. In spite of failure analysis, "unanticipated failures"-like those involving the uncommaded rudder movements that brought down USAir Flight 427 and United 585 or failures responsible for the space shuttle Challenger and Three Mile Island-are often unpredictable. Implicitly, what was conveyed, then, in CNN's warning, No Survivors-Why TWA Flight 800 Could Happen Again, was that we, the news-reading, news-watching public, had survived at least long enough to brace ourselves.

"No cameras," says the head of survival factors. "We've been asked to respect this request by the surviving family members." I lay down my camera, shake off the disappointment, and follow the group into the hangar.

The reconstruction required the building of a steel truss around which framing and mesh could support the pieces of TwA Flight 800 that arrived at the NTSB training center in an unmarked truck in the middle of the night. They didn't want some guy driving his wife and kids to Disney World to have to have to pass it on the freeway: Don't mind that truck next to us, kids. It's just the wreckage of Flight 8oo. Aren't you glad we drove? The largest and heaviest were lifted with a crane and a forklift. Smaller pieces were hung using bolts and wire, coil rods and rivets. One hundred pieces were hung each day for three months. An open floor allowed easy installation of recovered seats, which were reattached to the mounting tracks like broken bones that have been improperly set. 
At one end of the hangar sits a J41 prop-plane. Despite its own troubled past, the J41 appears naïve and perky in the shadow of TwA Flight 80o, which looms in the corner like a child's drawing of God. What is not rendered in the ninety-by-twenty-foot reconstructed fuselage is stored along the walls in dumpsters: busted servo valves, pylons, and fasteners, tagged, color-coded, and numbered. The color corresponds to the area, the number to the physical piece. There are millions of pieces.

After Dad failed to return us to Mom at The Spring, he brought us to a different kind of house filled with women: acquaintances or lovers or future secretaries. During the day he practiced law; at night he returned to put us to bed. After a week I arrived at my Catholic school in a wrinkled uniform, my hair un-brushed. Nervous whispering among the nuns culminated that afternoon in the church rectory, where Dad screamed some lines from a Kenny Rogers song to a woman named Lucille and Mom sat crying across from the priest. The priest grew weary. "I'm not going to tell you to stay married to him," he said. Mom stopped crying. What followed resembled deleted scenes from a Cassavetes film. On the surface of every table and countertop, inside drawers and cabinets, in the instep of shoes and on appliances, he had written: I Love You, Diane. Guns were traded for cars. Cars for back child support. Back child support delivered in briefcases filled with one-dollar bills. Court orders demanded returns of everything from stolen eyeglasses to my three-year-old brother. After Mom moved us back to Chicago, there were regular visits to Tampa. During these, impulses overcame him. On our way to the beach, we might find ourselves in the airport gift shop, wearing bathing suits and Kool-Aid-stained mouths, unaware that in an era of mechanical failures and accidental shoot-downs our weeks-early arrival at Mom's was about to be negotiated somewhere over Tennessee at 37,00o feet. An hour later, after all the questions and the protests, we gathered our bags of Jelly Bellies and Precious Moments dolls, belted ourselves in, and watched the chaos grow smaller and further from our line of sight, until it was nothing more than an elaborate and beautiful Cartesian coordinate. 